Available online at http://jurnal.goretanpena.com/index.php/JSSR

\title{
IMPLEMENTASI METODE VIKOR SEBAGAI PENDUKUNG KEPUTUSAN PENENTUAN KARYAWAN PENERIMA REWARD
}

\author{
Masitah Handayani ${ }^{1}$, Nasrun Marpaung ${ }^{2}$ \\ STMIK Royal, Kisaran \\ e-mail: ${ }^{1}$ bungafairuz8212@gmail.com
}

\begin{abstract}
Information technology that develops in society has a very large influence in various aspects of life. With the information technology, people can streamline and streamline their work. One of the uses of information technology is in determining the reward recipient employees objectively based on predetermined criteria. Employees are one of the resources owned in an agency, where in carrying out their duties employees are required to produce superior performance. As compensation for the performance that has been done by an employee, the agency provides wages or basic salary. Provision of basic salary to employees is carried out by the agency in accordance with the employment contract In addition to the basic salary, each agency sometimes provides rewards. Rewards can be given once a year or several years. The VIKOR method is one of the methods used in the decision-making process, for example in giving rewards. With the reward, each employee tries to show his best performance that can benefit the agency. The minimum alternative index value (Qi) is obtained by the 20 alternative with a Qi value of 0.00 .
\end{abstract}

Keywords: VIKOR Method, Decision Support System, Employee

\begin{abstract}
Abstrak: karyawan penerima reward secara objektif berdasarkan kriteria yang telah ditetapkan. Karyawan adalah salah satu sumberdaya yang dimiliki dalam suatu instansi, dimana dalam melaksanakan tugasnya karyawan dituntut untuk menghasilkan kinerja yang unggul. Sebagai kompensasi dari kinerja yang sudah dilakukan oleh seorang karyawan, instansi memberikan upah atau gaji pokok. Pemberian gaji pokok pada karyawan dilakukan oleh instansi sesuai dengan kontrak kerja. Di samping gaji Teknologi informasi yang berkembang di masyarakat memberi pengaruh yang sangat besar dalam berbagai aspek kehidupan. Dengan adanya teknologi informasi, masyarakat dapat mengefektifkan serta mengefisiensikan pekerjaan mereka. Salah satu pemanfaatan teknologi informasi adalah dalam menentukan pokok, setiap instansi kadangkala memberikan reward. Reward diberikan bisa setahun sekali atau beberapa tahun sekali. Metode VIKOR merupakan salah satu metode yang digunakan dalam proses pengambilan keputusan, misalnya dalam pemberian reward. Dengan adanya reward masing-masing karyawan berusaha untuk menunjukkan kinerja terbaiknya yang dapat menguntungkan instansi. Nilai indeks alternatif minimum $\left(\mathrm{Q}_{\mathrm{i}}\right)$ diperoleh alternatif ke-20 dengan nilai $\mathrm{Q}_{\mathrm{i}}$ adalah 0,00 .
\end{abstract}

Kata kunci: Metode VIKOR, Sistem Pendukung Keputusan, Karyawan

\section{PENDAHULUAN}

Pada

zaman

sekarang,

perkembangan IPTEK adalah salah satu komponen penting di seluruh lapisan masyarakat. Dengan adanya teknologi informasi dapat mempermudah masyarakat dalam melakukan pekerjaannya. Teknologi informasi juga dapat diimplementasikan di seluruh aspek kehidupan, diantaranya adalah untuk menentukan penerima reward. 
Available online at http://jurnal.goretanpena.com/index.php/JSSR

Karyawan adalah salah satu sumberdaya dalam suatu organisasi Setiap organisasi, tentunya harus memiliki sumberdaya yang unggul. Sumberdaya tersebut dipilih untuk menunjang aktifitas organisasi agar terjadi peningkatan operasional suatu organisasi dari tahun ke tahun. Karyawan yang unggul pasti memiliki kinerja yang baik pula sehingga mereka akan mendapatkan reward dari hasil kerja mereka. Bentuk reward yang diberikan oleh organisasi bermacammacam. Reward diberikan bisa setahun sekali atau beberapa tahun sekali. Reward ada yang diberikan dalam bentuk uang ataupun barang, dimana pemberian reward tergantung pada kebijakan pimpinan organisasi. Reward yang diberikan didasarkan pada kriteria-kriteria tertentu yang ditentukan oleh masingmasing organisasi. Pemberian reward yang dilakukan secara subjektif menimbulkan kecemburuan diantara sesama karyawan. Hal ini menyebabkan diantara karyawan merasa diperlakukan tidak adil padahal mereka sudah bekerja sesuai dengan job description masingmasing.

Pada penelitian ini, untuk memberikan reward kepada karyawan maka dalam penulisan artikel ilmiah ini menggunakan metode VIKOR sebagai pendukung keputusan secara objektif. Proses penentuan ini melibatkan banyak kriteria yang di nilai atau multikeriteria, maka dalam penyelesainya diperlukan sistem pendukung keputusan multikriteria. (Tumanggor et al., 2018) (Hanif et al., 2020)

Metode ini dianggap tepat kerena metode VIKOR biasanya diigunakan untuk menentukan peringkat dan pemilihan dari sekumpulan alternatif dan kriteria yang saling bertentangan untuk dapat mencapai keputusan akhir. (Rofiqo et al., 2018)

\section{Reward}

Reward adalah upah yang diberikan kepada manusia yang bekerja, dimana jumlah yang didapat berbeda sesuai dengan lembaga masing-masing. Reward yang diberikan biasanya disesuaikan dengan hak dan kewajibannya.

Reward dipengaruhi oleh interaksi antara manusia dengan lingkungan organisasi, pada saat tertentu manusia terangsang dengan insentif ekonomi atau materi (material insentive) atau keuntungankeuntungan ekonomi (economic rewards).

\section{Sistem Pendukung Keputusan}

Sistem pendukung keputusan adalah suatu sistem informasi spesifik yang ditujukan untuk membantu manajemen dalam mengambil keputusan yang berkaitan dengan persoalan yang bersifat semi terstruktur , dimana sistem pendukung keputusan membantu pengambil keputusan yang melengkapi mereka dengan informasi dari data yang telah diolah dengan relevan dan diperlukan untuk membuat keputusan tentang suatu masalah dengan lebih cepat dan akurat. (Handayani et al., 2019)

Komponen Sistem Pendukung Keputusan terdiri dari 4 bagian yaitu:

a. Data Management, berbentuk database yang didalamnya terdapat data sesuai dengan kebutuhan, data tersebut diatur oleh software yang disebut Database Management System (DBMS)

b. Model Management, memiliki kemapuan untuk melakukan proses analisa sesuai dengan kebutuhan. Communication (Dialog Subsystem). Sebagai antarmukauntuk melakukan komunikasi.

c. Konwledge Management. Sussistem optional ini dapat mendukung subsistem lain atau bertindak sebagai komponen yang berdiri sendiri.

\section{Metode VIKOR}

Konsep dasar Metode VIKOR adalah menentukan ranking dari sampelsampel yang ada dengan melihat hasil dari 
Available online at http://jurnal.goretanpena.com/index.php/JSSR

nilai-nilai utilitas dan regrets dari setiap sampel. Metode VIKOR telah digunakan oleh beberapa peneliti dalam MCDM. (Suniantara \& Suwardika, 2018)

MCDM adalah suatu metode pengambilan keputusan untuk menetapkan alternatif terbaik dari sejumlah alternatif berdasarkan beberapa kriteria tertentu. Tujuan MCDM adalah mengevaluasi $\mathrm{m}$ alternatif $A i$ (i $=$ $1,2, \ldots, \mathrm{m})$ terhadap sekumpulan kriteria $C j$ $(\mathrm{j}=1,2, \ldots, \mathrm{n})$. Matriks keputusan setiap alternatif terhadap setiap kriteria diberikan sebagai berikut:

$$
X=\left[\begin{array}{cccc}
X_{11} & X_{12} & \ldots & X_{1 n} \\
X_{21} & X_{22} & \ldots & X_{2 n} \\
\ldots & \ldots & \ldots & \ldots \\
X_{m 1} & X_{m 2} & \ldots & X_{m n}
\end{array}\right\rfloor
$$

Nilai bobot yang menunjukkan tingkat kepentingan relatif setiap kriteria adalah sebagai berikut:

$$
\begin{aligned}
& w=\left(w_{1}, w_{2}, \ldots, w_{n}\right) \ldots \\
& \ldots(2) \\
& W_{j}=\frac{w_{j}}{\sum_{j=1}^{n} w_{j}}
\end{aligned}
$$

Keterangan :

$w j=$ nilai bobot kriteria ke- $\mathrm{j}, \mathrm{j}=1,2, \ldots$, $\mathrm{n}$

$u j=$ rata-rata penilaian responden terhadap bobot kriteria ke-j. (Ramadhani et al., 2019)

Metode

VIKOR

(VIseKriterijumska Optimizacija I Kompromisno Resenje) adalah metode optimasi multikriteria yang digunakan dalam sistem yang kompleks. Metode ini berfokus pada perangkingan dan memilih dari satu set alternatif, dan menentukan solusi kompromi untuk masalah kriteria yang bertentangan, yang dapat membantu para pengambil keputusan untuk mencapai keputusan akhir. (Kristyawan, 2017)

Adapun langkah-langkah penyelesaian metode VIKOR antara lain :

1. Normalisasi matriks keputusan

$$
\mathrm{r}_{\mathrm{ij}}=\left(\frac{\mathrm{x}_{\mathrm{j}}{ }^{+}-\mathrm{x}_{\mathrm{ij}}}{\mathrm{x}_{\mathrm{j}}^{+}-\mathrm{x}_{\mathrm{j}}^{-}}\right)
$$

Keterangan:

$\mathrm{X}_{\mathrm{ij}}=$ nilai dari matriks pengambilan keputusan

$\mathrm{X}_{\mathrm{j}}^{+}=$nilai maksimum dalam satu kriteria

$\mathrm{X}_{\mathrm{j}}^{-}=$nilai minimum dalam satu kriteria

2. Menormalisasikan bobot (W*) masing-masing kriteria $\left(\mathrm{w}_{\mathrm{j}}\right)$ kemudian mengalikan dengan $\mathrm{r}_{\mathrm{ij}}$

$W^{*}=\frac{w_{j}}{\sum W_{j}}$

3. Menghitung nilai utility measures (S) dan regret measures $(\mathrm{R})$

$S_{i}=\sum_{j=1}^{n} W_{j} \frac{f_{j}{ }^{+}-f_{i j}}{f_{j}{ }^{+}-f_{j}{ }^{-}}$

Nilai $\mathrm{S}_{\mathrm{i}}$ merupakan hasil penjumlahan nilai kriteria ke- 1 sampai kriteria ke- $n$ pada alternatif ke-i, sedangkan

$$
R_{i}=\max _{i}\left[W_{j} \frac{\left(f_{j}{ }^{+}-f_{i j}\right)}{\left(f_{j}{ }^{+}-f_{j}{ }^{-}\right)}\right]
$$

Nilai Ri merupakan nilai maksimal berdasarkan perbandingan nilai kriteria ke- 1 sampai keriteria ke- $n$ pada alternatif ke- $i$

4. Menghitung nilai indeks $\operatorname{VIKOR}\left(\mathrm{Q}_{\mathrm{i}}\right)$

$Q_{i}=v\left[\frac{S_{i}-S^{-}}{S^{+}-S^{-}}\right]+(1-v)\left[\frac{R_{i}-R^{-}}{R^{+}-R^{-}}\right]$

Keterangan:

$\mathrm{S}^{-}=$nilai minimum dari $\mathrm{S}_{\mathrm{i}}$

$\mathrm{S}^{+}=$nilai maksimum dari $\mathrm{S}_{\mathrm{i}}$

$\mathrm{R}^{-}=$nilai minimum dari $\mathrm{R}_{\mathrm{i}}$

$\mathrm{R}^{+}=$nilai maksimum dari $\mathrm{R}_{\mathrm{i}}$

$\mathrm{V}=$ nilai ketetapan $(0,5)$

Semakin kecil nilai indeks vikor (Qi) maka semakin baik pula solusi dari alternatif tersebut.(Mesran et al., 2020) 
Available online at http://jurnal.goretanpena.com/index.php/JSSR

\section{METODE}

Metode penelitian merupakan suatu cara atau jalan untuk memperoleh kembali pemecahan terhadap segala permasalahan. Di dalam penelitian dikenal adanya beberapa macam teori untuk menerapkan salah satu metode yang relevan terhadap permasalahan tertentu.

Adapun metode penelitian yang dilakukan terdiri dari beberapa tahap yaitu:

1. Identifikasi dan analisa masalah

2. Studi Literatur

3. Implementasi Metode VIKOR

4. Pengujian Metode VIKOR

\section{HASIL DAN PEMBAHASAN}

Berdasarkan hasil dari pengumpulan data yang telah dilakukan dengan membandingkan antara alternatif dan kriteria dalam pemilihan penerima reward menggunakan Metode VIKOR dengan jumlah alternatif 20 (dua puluh) dan 4 (empat) kriteria, maka:

1. Menentukan jenis-jenis kriteria dan alternatif, alternatif dalam penelitian ini adalah karyawan yang akan diberikan reward berkala sebanyak 20 orang karyawan.

Tabel 1. Alternatif

\begin{tabular}{|r|l|}
\hline No & \multicolumn{1}{|c|}{ Nama Karyawan } \\
\hline 1 & Budi Irawan \\
\hline 2 & Nanda Pratama \\
\hline 3 & Fajar Alamsyah \\
\hline 4 & Mandra Halim \\
\hline 5 & Nurman Syaiful \\
\hline 6 & Dika Syahputra \\
\hline 7 & Agus Harmansyah \\
\hline 8 & Raja Halim Indarto \\
\hline 9 & Hilman \\
\hline 10 & Muhammad Zikri \\
\hline 11 & Aman Makmur \\
\hline 12 & Mardito Ahmad \\
\hline
\end{tabular}

\begin{tabular}{|r|l|}
\hline No & \multicolumn{1}{|c|}{ Nama Karyawan } \\
\hline 13 & Indra Syahputra \\
\hline 14 & Hermanto \\
\hline 15 & Zulham Efendi \\
\hline 16 & Andika Ariwinanda Nst \\
\hline 17 & Dwi Fajar Siregar \\
\hline 18 & Ahmad Agung Sitorus \\
\hline 19 & Johan Sitanggang \\
\hline 20 & Mahendra Ali Sidabutar \\
\hline
\end{tabular}

2. Kriteria yang akan di jadika acuan dalam pengambilan keputusan.

Tabel 2. Kriteria

\begin{tabular}{|c|c|}
\hline $\begin{array}{c}\text { Faktor } \\
\text { Benefit/Cost) }\end{array}$ & Kriteria \\
\hline Benefit & Kedisiplinan (C1) \\
\hline Benefit & Masa Kerja (C2) \\
\hline Benefit & Kinerja (C3) \\
\hline Benefit & Komunikasi (C4) \\
\hline
\end{tabular}

3. Menentukan bobot preferensi atau tingkat kepentingan (W) dari setiap kriteria.

Tabel 3. Bobot Kriteria

\begin{tabular}{|c|c|c|c|c|}
\hline Kriteria & $(\mathrm{C} 1)$ & $(\mathrm{C} 2)$ & $(\mathrm{C} 3)$ & $(\mathrm{C} 4)$ \\
\hline Bobot & 4 & 5 & 5 & 3 \\
\hline Benefit/Cost & $\mathrm{B}$ & $\mathrm{B}$ & $\mathrm{B}$ & $\mathrm{B}$ \\
\hline
\end{tabular}

4. Mengidentifikasi nilai bobot kriteria masing-masing kriteria.

Tabel 4. Skala Bobot Kriteria Kedisiplinan

\begin{tabular}{|c|c|c|}
\hline $\begin{array}{c}\text { Kedisplinan } \\
\left(\mathbf{C}_{\mathbf{1}}\right)\end{array}$ & Keterangan & Bobot \\
\hline$<=20 \%$ & $\begin{array}{c}\text { Sangat Tidak } \\
\text { Disiplin }\end{array}$ & 1 \\
\hline $20.01-40 \%$ & Tidak Disiplin & 2 \\
\hline $40.01-60 \%$ & $\begin{array}{c}\text { Cukup } \\
\text { Disiplin }\end{array}$ & 3 \\
\hline $60.01-80 \%$ & Disiplin & 4 \\
\hline$>80 \%$ & $\begin{array}{c}\text { Sangat } \\
\text { Disiplin }\end{array}$ & 5 \\
\hline
\end{tabular}


Available online at http://jurnal.goretanpena.com/index.php/JSSR

Tabel 5. Skala Bobot Kriteria Masa
\begin{tabular}{|c|c|c|}
\hline $\begin{array}{c}\text { Masa Kerja } \\
(\text { C2) }\end{array}$ & Keterangan & Bobot \\
\hline$\leq 3$ tahun & $\begin{array}{c}\text { Sangat } \\
\text { Rendah } \\
(\text { SR })\end{array}$ & 1 \\
\hline $\begin{array}{c}3.01-5.00 \\
\text { tahun }\end{array}$ & Rendah (R) & 2 \\
\hline $\begin{array}{c}5.01-7.00 \\
\text { tahun }\end{array}$ & Cukup (C) & 3 \\
\hline $\begin{array}{c}7.01-9.00 \\
\text { tahun }\end{array}$ & Tinggi (T) & 4 \\
\hline$>10$ tahun & $\begin{array}{c}\text { Sangat } \\
\text { Tinggi (ST) }\end{array}$ & 5 \\
\hline
\end{tabular}

Tabel 6. Skala Bobot Kriteria Kinerja

\begin{tabular}{|l|c|}
\hline \multicolumn{1}{|c|}{ Keterangan } & Bobot \\
\hline Sangat Baik Sekali & 5 \\
\hline Baik & 4 \\
\hline Cukup Baik & 3 \\
\hline Tidak Baik & 2 \\
\hline Sangat Tidak Baik & 1 \\
\hline
\end{tabular}

Tabel 7. Skala Bobot Kriteria Komunikasi

\begin{tabular}{|l|c|}
\hline \multicolumn{1}{|c|}{ Keterangan } & Bobot \\
\hline Sangat Baik Sekali & 5 \\
\hline Baik & 4 \\
\hline Cukup Baik & 3 \\
\hline Tidak Baik & 2 \\
\hline Sangat Tidak Baik & 1 \\
\hline
\end{tabular}

Adapun tabel penilaian alternatif untuk masing-masing kriteria dapat dilihat pada tabel berikut:

Tabel 8. Bobot Kriteria

Pada Masing-Masing Alternatif

\begin{tabular}{|c|c|c|c|c|c|}
\hline \multirow{2}{*}{ No } & \multirow{2}{*}{$\mathrm{A}_{\mathrm{i}}$} & \multicolumn{4}{|c|}{$\mathrm{C}_{\mathrm{i}}$} \\
\cline { 3 - 6 } & & $\mathrm{C} 1$ & $\mathrm{C} 2$ & $\mathrm{C} 3$ & $\mathrm{C} 4$ \\
\hline 1 & $\mathrm{~A} 1$ & 2 & 2 & 5 & 3 \\
\hline 2 & $\mathrm{~A} 2$ & 4 & 4 & 3 & 3 \\
\hline 3 & $\mathrm{~A} 3$ & 3 & 4 & 5 & 4 \\
\hline
\end{tabular}

\begin{tabular}{|c|c|c|c|c|c|}
\hline \multirow{2}{*}{ No } & \multirow{2}{*}{$\mathrm{A}_{\mathrm{i}}$} & \multicolumn{5}{|c|}{$\mathrm{C}_{\mathrm{i}}$} \\
\cline { 3 - 6 } & & $\mathrm{C} 1$ & $\mathrm{C} 2$ & $\mathrm{C} 3$ & $\mathrm{C} 4$ \\
\hline 4 & $\mathrm{~A} 4$ & 3 & 4 & 3 & 2 \\
\hline 5 & $\mathrm{~A} 5$ & 3 & 1 & 2 & 5 \\
\hline 6 & $\mathrm{~A} 6$ & 4 & 3 & 3 & 5 \\
\hline 7 & $\mathrm{~A} 7$ & 3 & 4 & 3 & 5 \\
\hline 8 & $\mathrm{~A} 8$ & 2 & 4 & 4 & 3 \\
\hline 9 & $\mathrm{~A} 9$ & 4 & 4 & 4 & 3 \\
\hline 10 & $\mathrm{~A} 10$ & 5 & 4 & 4 & 3 \\
\hline 11 & $\mathrm{~A} 11$ & 5 & 4 & 2 & 4 \\
\hline 12 & $\mathrm{~A} 12$ & 4 & 2 & 2 & 2 \\
\hline 13 & $\mathrm{~A} 13$ & 4 & 1 & 3 & 2 \\
\hline 14 & $\mathrm{~A} 14$ & 4 & 2 & 3 & 3 \\
\hline 15 & $\mathrm{~A} 15$ & 3 & 3 & 3 & 2 \\
\hline 16 & $\mathrm{~A} 16$ & 4 & 1 & 4 & 3 \\
\hline 17 & $\mathrm{~A} 17$ & 4 & 2 & 3 & 3 \\
\hline 18 & $\mathrm{~A} 18$ & 4 & 1 & 4 & 2 \\
\hline 19 & $\mathrm{~A} 19$ & 5 & 4 & 3 & 2 \\
\hline 20 & A20 & 5 & 4 & 5 & 5 \\
\hline Benefit/Cost & B & B & B & B \\
\hline Maximum & $\mathbf{5}$ & $\mathbf{4}$ & $\mathbf{5}$ & $\mathbf{5}$ \\
\hline Minimum & $\mathbf{2}$ & $\mathbf{1}$ & $\mathbf{2}$ & $\mathbf{2}$ \\
\hline Weight & $\mathbf{4}$ & $\mathbf{5}$ & $\mathbf{5}$ & $\mathbf{3}$ \\
\hline
\end{tabular}

5.Membuat matriks rating kinerjaternormalisasi $\quad r_{i j} \quad$ sebagai berikut:

$R_{i j, j}=\left[\begin{array}{llll}1,00 & 0,67 & 0,00 & 0,67 \\ 0,33 & 0,00 & 0,67 & 0,67 \\ 0,67 & 0,00 & 0,00 & 0,33 \\ 0,67 & 0,00 & 0,67 & 1,00 \\ 0,67 & 1,00 & 1,00 & 0,00 \\ 0,33 & 0,33 & 0,67 & 0,00 \\ 0,67 & 0,00 & 0,67 & 0,00 \\ 1,00 & 0,00 & 0,33 & 0,67 \\ 0,33 & 0,00 & 0,33 & 0,67 \\ 0,00 & 0,00 & 0,33 & 0,67 \\ 0,00 & 0,00 & 1,00 & 0,33 \\ 0,33 & 0,67 & 1,00 & 1,00 \\ 0,33 & 1,00 & 0,67 & 1,00 \\ 0,33 & 0,67 & 0,67 & 0,67 \\ 0,67 & 0,33 & 0,67 & 1,00 \\ 0,33 & 1,00 & 0,33 & 0,67 \\ 0,33 & 0,67 & 0,67 & 0,67 \\ 0,33 & 1,00 & 0,33 & 1,00 \\ 0,00 & 0,00 & 0,67 & 1,00 \\ 0,00 & 0,00 & 0,00 & 0,00\end{array}\right]$


Available online at http://jurnal.goretanpena.com/index.php/JSSR

6.menormalisasikan bobot (W*) masingmasing kriteria $\left(\mathrm{w}_{\mathrm{j}}\right)$ kemudian mengalikan dengan $r_{i j}$

$$
\begin{array}{ll}
W_{1}=\frac{4}{17}=0,24 & W_{3}=\frac{5}{17}=0,29 \\
W_{2}=\frac{5}{17}=0,29 & W_{4}=\frac{3}{17}=0,18
\end{array}
$$

yang dapat dilihat pada matriks berikut ini:

$R_{i j}=\left[\begin{array}{llll}1,00 & 0,67 & 0,00 & 0,67 \\ 0,33 & 0,00 & 0,67 & 0,67 \\ 0,67 & 0,00 & 0,00 & 0,33 \\ 0,67 & 0,00 & 0,67 & 1,00 \\ 0,67 & 1,00 & 1,00 & 0,00 \\ 0,33 & 0,33 & 0,67 & 0,00 \\ 0,67 & 0,00 & 0,67 & 0,00 \\ 1,00 & 0,00 & 0,33 & 0,67 \\ 0,33 & 0,00 & 0,33 & 0,67 \\ 0,00 & 0,00 & 0,33 & 0,67 \\ 0,00 & 0,00 & 1,00 & 0,33 \\ 0,33 & 0,67 & 1,00 & 1,00 \\ 0,33 & 1,00 & 0,67 & 1,00 \\ 0,33 & 0,67 & 0,67 & 0,67 \\ 0,67 & 0,33 & 0,67 & 1,00 \\ 0,33 & 1,00 & 0,33 & 0,67 \\ 0,33 & 0,67 & 0,67 & 0,67 \\ 0,33 & 1,00 & 0,33 & 1,00 \\ 0,00 & 0,00 & 0,67 & 1,00 \\ 0,00 & 0,00 & 0,00 & 0,00\end{array}\right]$

$W^{*}\left[\begin{array}{llll}0,24 & 0,29 & 0,29 & 0,18\end{array}\right]$

Sehingga hasilnya dapat dilihat ada tabel berikut:

\section{Tabel 9. Hasil Perkalian $\mathbf{R}_{\mathrm{ij}}$ dengan}

$\mathbf{W}_{\mathrm{j}}$

\begin{tabular}{|c|c|c|c|c|c|}
\hline \multirow{2}{*}{ No } & \multirow{2}{*}{$\mathbf{A}_{\mathbf{i}}$} & \multicolumn{4}{|c|}{$\mathbf{C}_{\mathbf{i}}$} \\
\cline { 3 - 6 } & & $\mathbf{C 1}$ & $\mathbf{C 2}$ & $\mathbf{C 3}$ & $\mathbf{C 4}$ \\
\hline 1 & A1 & 0,24 & 0,20 & 0,00 & 0,12 \\
\hline 2 & A2 & 0,08 & 0,00 & 0,20 & 0,12 \\
\hline 3 & A3 & 0,16 & 0,00 & 0,00 & 0,06 \\
\hline 4 & A4 & 0,16 & 0,00 & 0,20 & 0,18 \\
\hline 5 & A5 & 0,16 & 0,29 & 0,29 & 0,00 \\
\hline 6 & A6 & 0,08 & 0,10 & 0,20 & 0,00 \\
\hline 7 & A7 & 0,16 & 0,00 & 0,20 & 0,00 \\
\hline 8 & A8 & 0,24 & 0,00 & 0,10 & 0,12 \\
\hline
\end{tabular}

\begin{tabular}{|c|c|c|c|c|c|}
9 & A9 & 0,08 & 0,00 & 0,10 & 0,12 \\
\hline 10 & A10 & 0,00 & 0,00 & 0,10 & 0,12 \\
\hline 11 & A11 & 0,00 & 0,00 & 0,29 & 0,06 \\
\hline 12 & A12 & 0,08 & 0,20 & 0,29 & 0,18 \\
\hline 13 & A13 & 0,08 & 0,29 & 0,20 & 0,18 \\
\hline 14 & A14 & 0,08 & 0,20 & 0,20 & 0,12 \\
\hline 15 & A15 & 0,16 & 0,10 & 0,20 & 0,18 \\
\hline 16 & A16 & 0,08 & 0,29 & 0,10 & 0,12 \\
\hline 17 & A17 & 0,08 & 0,20 & 0,20 & 0,12 \\
\hline 18 & A18 & 0,08 & 0,29 & 0,10 & 0,18 \\
\hline 19 & A19 & 0,00 & 0,00 & 0,20 & 0,18 \\
\hline 20 & A20 & 0,00 & 0,00 & 0,00 & 0,00 \\
\hline
\end{tabular}

6. Menghitung nilai $\mathrm{S}$ dan $\mathrm{R}$

Nilai $S_{i}$ merupakan penjumlahan antar nilai kriteria pada alternatif ke-i

$S_{1}=0,24+0,20+0,00+0,12=0,55$
$S_{2}=0,08+0,00+0,20+0,12=0,39$
$S_{3}=0,16+0,00+0,00+0,06=0,22$
$S_{4}=0,16+0,00+0,20+0,18=0,53$
$S_{5}=0,16+0,29+0,29+0,00=0,75$
$S_{6}=0,08+0,10+0,20+0,00=0,37$
$S_{7}=0,16+0,00+0,20+0,00=0,35$
$S_{8}=0,24+0,00+0,10+0,12=0,45$
$S_{9}=0,08+0,00+0,10+0,12=0,29$
$S_{10}=0,00+0,00+0,10+0,12=0,22$
$S_{11}=0,00+0,00+0,29+0,06=0,35$
$S_{12}=0,08+0,20+0,29+0,18=0,75$
$S_{13}=0,08+0,29+0,20+0,18=0,75$
$S_{14}=0,08+0,20+0,20+0,12=0,59$
$S_{15}=0,16+0,10+0,20+0,18=0,63$
$S_{16}=0,08+0,29+0,10+0,12=0,59$
$S_{17}=0,08+0,20+0,20+0,12=0,59$
$S_{18}=0,08+0,29+0,10+0,18=0,65$
$S_{19}=0,00+0,00+0,20+0,18=0,37$
$S_{20}=0,00+0,00+0,00+0,00=0,00$

Berdasarkan nilai $\mathrm{S}_{1}$ sampai $\mathrm{S}_{20}$ dapat diketahui masing-masing nilai maksimum $\mathrm{S}^{+}$adalah 0,75 dan minimum $\mathrm{S}^{-}$adalah 0,00 . 
Available online at http://jurnal.goretanpena.com/index.php/JSSR

Untuk Nilai $\mathrm{R}_{\mathrm{i}}$ merupakan nilai maksimum antar nilai kriteria pada alternatif ke-i, sehingga nilai $\mathrm{R}_{1}$ sapai

$$
\begin{aligned}
& R_{I}=\max (0,24: 0,20: 0,00: 0,12)=0,24^{Q_{6}=0,5\left[\frac{0,37-0,00}{0,75-0,00}\right]+0,5\left[\frac{0,20-0,00}{0,29-0,00}\right]} \\
& \begin{array}{l}
R_{2}=\max (0,08: 0,00: 0,20: 0,12)=0,20 \\
R_{3}=\max (0,16: 0,00: 0,00: 0,06)=0,16^{Q_{7}}=0,5\left[\frac{0,35-0,00}{0,75-0,00}\right]+0,5\left[\frac{0,20-0,00}{0,29-0,00}\right]
\end{array} \\
& R_{4}=\max (0,16: 0,00: 0,20: 0,18)=0,20=0,57 \\
& \begin{array}{l}
R_{4}=\max (0,16: 0,00: 0,20: 0,18)=0,20 \\
R_{5}=\max (0,16: 0,29: 0,29: 0,00)=0,29 Q_{\Omega}=0,5\left[\frac{0,45-0,00}{0,75-0,00}\right]+0,5\left[\frac{0,24-0,00}{0,29-0,00}\right]
\end{array} \\
& R_{6}=\max (0,08: 0,10: 0,20: 0,00)=0,20=0,70 \\
& R_{7}=\max (0,16: 0,00: 0,20: 0,00)=0,20_{Q_{9}}=0,5\left[\frac{0,29-0,00}{0,75-0,00}\right]+0,5\left[\frac{0,12-0,00}{0,29-0,00}\right] \\
& R_{8}=\max (0,24: 0,00: 0,10: 0,12)=0,24=0,40 \\
& \begin{array}{l}
R_{9}=\max (0,08: 0,00: 0,10: 0,12)=0,12 Q_{10}=0,5\left[\frac{0,22-0,00}{0,75-0,00}\right]+0,5\left[\frac{0,12-0,00}{0,29-0,00}\right] \\
R_{10}=\max (0,00: 0,00: 0,10: 0,12)=0,12
\end{array} \\
& R_{l l}=\max (0,00: 0,00: 0,29: 0,06)=0,29 \quad=0,34 \\
& R_{12}=\max (0,08: 0,20: 0,29: 0,18)=0,29 Q_{11}=0,5\left[\frac{0,35-0,00}{0,75-0,00}\right]+0,5\left[\frac{0,29-0,00}{0,29-0,00}\right] \\
& R_{13}=\max (0,08: 0,29: 0,20: 0,18)=0,29=0,74 \\
& R_{14}=\max (0,08: 0,20: 0,20: 0,12)=0,20 Q_{12}=0,5\left[\frac{0,75-0,00}{0,75-0,00}\right]+0,5\left[\frac{0,29-0,00}{0,29-0,00}\right] \\
& R_{15}=\max (0,16: 0,10: 0,20: 0,18)=0,20 \quad=1,00 \\
& R_{17}=\max (0,08: 0,20: 0,20: 0,12)=0,20=1,00 \\
& \begin{array}{l}
R_{18}=\max (0,08: 0,29: 0,10: 0,18)=0,29 \\
R_{19}=\max (0,00: 0,00: 0,20: 0,18)=0,20 Q_{14}=0,5\left[\frac{0,59-0,00}{0,75-0,00}\right]+0,5\left[\frac{0,20-0,00}{0,29-0,00}\right]
\end{array} \\
& R_{20}=\max (0,00: 0,00: 0,00: 0,00)=0,00 \quad=0,73
\end{aligned}
$$

Berdasarkan nilai $\mathrm{R}_{1}$ sampai $\mathrm{R}_{20}$ dapat

diketahui masing-masing nilai maksimum $\mathrm{R}^{+}$adalah 0,29 dan minimum $\mathrm{R}^{-}$adalah 0,00 .

7.

enghitung nilai indeks $\operatorname{VIKOR}\left(\mathrm{Q}_{\mathrm{i}}\right)$

$$
Q_{i}=v\left[\frac{S_{i}-S^{-}}{S^{+}-S^{-}}\right]+(1-v)\left[\frac{R_{i}-R^{-}}{R^{+}-R^{-}}\right]
$$

$$
\begin{aligned}
Q_{15} & =0,5\left[\frac{0,63-0,00}{0,75-0,00}\right]+0,5\left[\frac{0,20-0,00}{0,29-0,00}\right] \\
& =0,75
\end{aligned}
$$

$$
\begin{aligned}
Q_{16} & =0,5\left[\frac{0,59-0,00}{0,75-0,00}\right]+0,5\left[\frac{0,29-0,00}{0,29-0,00}\right] \\
& =0,89
\end{aligned}
$$

$$
Q_{17}=0,5\left[\frac{0,59-0,00}{0,75-0,00}\right]+0,5\left[\frac{0,20-0,00}{0,29-0,00}\right]
$$$$
=0,73
$$

$$
Q_{18}=0,5\left[\frac{0,65-0,00}{0,75-0,00}\right]+0,5\left[\frac{0,29-0,00}{0,29-0,00}\right]
$$$$
=0,93
$$

$$
\begin{aligned}
Q_{1} & =0,5\left[\frac{0,55-0,00}{0,75-0,00}\right]+0,5\left[\frac{0,24-0,00}{0,29-0,00}\right] \\
& =0,77
\end{aligned}
$$

$Q_{2}=0,5\left[\frac{0,39-0,00}{0,75-0,00}\right]+0,5\left[\frac{0,20-0,00}{0,29-0,00}\right]$ $=0,60$

$$
\begin{aligned}
Q_{a} & =0,5\left[\frac{0,22-0,00}{0,75-0,00}\right]+(-0,5)\left[\frac{0,16-0,00}{0,29-0,00}\right] \\
Q_{4} & =0,5\left[\frac{0,53-0,00}{0,75-0,00}\right]+0,5\left[\frac{0,20-0,00}{0,29-0,00}\right] \\
& =0,69
\end{aligned}
$$$$
Q_{19}=0,5\left[\frac{0,37-0,00}{0,75-0,00}\right]+0,5\left[\frac{0,20-0,00}{0,29-0,00}\right]
$$$$
=0,58
$$$$
Q_{20}=0,5\left[\frac{0,00-0,00}{0,75-0,00}\right]+0,5\left[\frac{0,00-0,00}{0,29-0,00}\right]
$$$$
=0,00
$$ 
Available online at http://jurnal.goretanpena.com/index.php/JSSR

Tabel10. Nilai Indeks Vikor $\left(Q_{i}\right)$

Pada Masing-Masing Alternatif

\begin{tabular}{|c|c|c|c|}
\hline No & $\mathbf{A}_{\mathbf{i}}$ & $\begin{array}{c}\text { Nilai Indeks } \\
\text { VIKOR }\left(\mathbf{Q}_{\mathbf{i}}\right)\end{array}$ & Ranking \\
\hline 1 & & & \\
\hline 2 & A1 & 0,77 & 15 \\
\hline 3 & A3 & 0,60 & 8 \\
\hline 4 & A4 & 0,41 & 4 \\
\hline 5 & A5 & 1,00 & 9 \\
\hline 6 & A6 & 0,58 & 6 \\
\hline 7 & A7 & 0,57 & 5 \\
\hline 8 & A8 & 0,70 & 10 \\
\hline $\mathbf{9}$ & A9 & $\mathbf{0 , 4 0}$ & $\mathbf{3}$ \\
\hline $\mathbf{1 0}$ & A10 & $\mathbf{0 , 3 4}$ & $\mathbf{2}$ \\
\hline 11 & A11 & 0,74 & 13 \\
\hline 12 & A12 & 1,00 & 19 \\
\hline 13 & A13 & 1,00 & 20 \\
\hline 14 & A14 & 0,73 & 11 \\
\hline 15 & A15 & 0,75 & 14 \\
\hline 16 & A16 & 0,89 & 16 \\
\hline 17 & A17 & 0,73 & 12 \\
\hline 18 & A18 & 0,93 & 17 \\
\hline 19 & A19 & 0,58 & 7 \\
\hline $\mathbf{2 0}$ & A20 & $\mathbf{0 , 0 0}$ & $\mathbf{1}$ \\
\hline & & & \\
\hline
\end{tabular}

Berdasarkan nilai hasil akhir yang diperoleh dari setiap proses yang telah dilakukan, maka nilai indeks VIKOR pada masing-masing alternatif $\left(\mathrm{Q}_{\mathrm{i}}\right)$ minimum adalah $\mathrm{Q}_{20}$ (Mahendra Ali Sidabutar), $\mathrm{Q}_{10}$ (Muhammad Zikri) dan $\mathrm{Q}_{9}$ (Hilman) dengan masing-masing nilai indeks VIKOR $\mathrm{Q}_{20}=0,00, \mathrm{Q}_{10}=0,34$, dan $\mathrm{Q}_{9}=0,40$

\section{SIMPULAN}

Berdasarkan penelitian yang dilakukan dalam pemilihan penerima reward bagi karyawan menggunakan Metode VIKOR, dapat disimpulkan bahwa :

1. Ada empat kriteria yang digunakan dalam proses pemilihan penerima reward berkala yaitu kedisiplinan, masa kerja, kinerja dan komunikasi.

2. Metode VIKOR dapat digunakan dalam proses pengambilan keputusan.

3. Sistem Pendukung Keputusan yang dibangun dengan Metode VIKOR dimulai dengan melakukan proses perhitungan rating kinerja ternormalisasi Rij, normalisasi bobot $\mathrm{W}^{*}$, selanjutnya menghitung nilai utility measures (S) dan regret measures (R) masing-masing alternatif. Tahap akhir adalah menhitung nilai indeks VIKOR $\mathrm{Q}_{\mathrm{i}}$. Alternatif terpilih adalah alternatif dengan nilai indeks VIKOR minimum, di mana alternatif tersebut akan mendapatkan reward. .

\section{DAFTAR PUSTAKA}

Handayani, M., Marpaung, N., \& Anggraini, S. (2019). Implementasi Metode Weighted Aggregated Sum Product Assesment (WASPAS) Dalam Pemilihan Karyawan Terbaik Berbasis Sistem Pendukung Keputusan. Prosiding Seminar Nasional Riset Information Science (SENARIS), $1, \quad 1098$. https://doi.org/10.30645/senaris.v1i0 .122

Hanif, K. H., Yudhana, A., \& Fadlil, A. (2020). Analisis Penilaian Guru Memakai Metode Visekriterijumsko Kompromisno Rangiranje (VIKOR). Jurnal Ilmiah Mandala Education, 6(1), 6-11. https://doi.org/10.36312/jime.v6i1.1 099 
Available online at http://jurnal.goretanpena.com/index.php/JSSR

Kristyawan, Y. (2017). Sistem Pendukung Keputusan Distribusi Rehabilitas Sosial Rumah Tidak Layak Huni pada Kab Sampang Menggunakan Metode Vikor. Jurnal INFORM, 2(2), $1-8$. https://doi.org/10.25139/ojsinf.v2i1. 402

Mesran, Ulfa, K., Utomo, D. P., \& Nasution, I. R. (2020). Penerapan Metode VlseKriterijumska Optimizacija I Kompromisno Resenje ( Vikor ) Dalam Pengangkatan Guru. ALGORITMA: Jurnal Ilmu Komputer Dan Informatika, 4(1), 265-271.

Ramadhani, A., Santoso2, R., \& Rahmawati, R. (2019). PEMILIHAN PERUMAHAN TERFAVORIT MENGGUNAKAN METODE VIKOR DAN TOPSIS DENGAN GUI MATLAB (Studi Kasus: Perumahan Mijen Semarang). Jurnal Gaussian, 8(3), 330-342.

https://doi.org/10.14710/j.gauss.v8i3 .26678
Rofiqo, N., Windarto, A. P., \& Wanto, A. (2018). Penerapan Metode VIKOR Pada Faktor Penyebab Rendahnya Minat Mahasiswa Dalam Menulis Artikel Ilmiah. Seminar Nasional Sains \& Teknologi Informasi (SENSASI), 1(1), 228-237.

Suniantara, I. K. P., \& Suwardika, G. (2018). Penerapan Metode VIKOR pada Pengambilan Keputusan Seleksi Calon Penerima Beasiswa Bidikmisi Universitas Terbuka. Intensif, 2(1), 24. https://doi.org/10.29407/intensif.v2i 1.11848

Tumanggor, H., Haloho, M., Ramadhani, P., \& Darma Nasution, S. (2018). Penerapan Metode VIKOR Dalam Penentuan Penerima Dana Bantuan Rumah Tidak Layak Huni. Jurikom, 5(1), 71-78. 